\title{
Geographical Distribution and Survival of Iris yellow spot virus in Spiny Sowthistle, Sonchus asper, in Georgia
}

C. Nischwitz, Department of Biology, Utah State University, Logan 84322; R. Srinivasan and S. Sundaraj, Department of Entomology, and S. W. Mullis, Department of Plant Pathology, University of Georgia, Coastal Plain Experiment Station, Tifton 31793-0748; B. McInnes, University of Georgia, Athens 30602; and R. D. Gitaitis, Department of Plant Pathology, University of Georgia, Coastal Plain Experiment Station, Tifton

\begin{abstract}
Nischwitz, C., Srinivasan, R., Sundaraj, S., Mullis, S. W., McInnes, B., and Gitaitis, R. D. 2012. Geographical distribution and survival of Iris yellow spot virus in spiny sowthistle, Sonchus asper, in Georgia. Plant Dis. 96:1165-1171.

Iris yellow spot virus (IYSV) has occurred in Georgia since 2003. IYSV is transmitted by onion thrips, Thrips tabaci. During a weed survey in the Vidalia onion-growing zone (VOZ), spiny sowthistle (Sonchus asper) was identified as a host for IYSV. Spiny sowthistle is widespread in Georgia, and this presented an opportunity to study the natural spread of IYSV and assess its potential role in IYSV epidemiology. From 2007 to 2009, during the spring season, 2,011 sowthistle samples were collected from various counties within and outside the VOZ. The samples were tested for IYSV infection by enzyme-linked immunosorbent assay and confirmed by reverse-transcrip-

tion polymerase chain reaction and sequencing. IYSV sequences from sowthistle were 98 to $99 \%$ identical to onion IYSV sequences from onion originated from Georgia. By the third year, IYSV-infected sowthistle plants were found in $79 \%$ of the counties in the VOZ and in $61 \%$ of the sampled counties in all directions, except to the east of the VOZ. Furthermore, thrips-mediated transmission assays confirmed that $T$. tabaci can efficiently transmit IYSV from onion to sowthistle. Sowthistle also supported T. tabaci survival and reproduction. These findings demonstrate that sowthistle plants can serve as an IYSV inoculum source and as a thrips reservoir.
\end{abstract}

Iris yellow spot virus (IYSV) is a member of the Tospovirus genus in the family Bunyaviridae (37). IYSV is known to infect plants belonging to at least sixteen families $(2,12,15-$ $17,21,26,28,38,39,44)$. Under favorable conditions, IYSV can severely impact onion production and yield $(17,18)$. IYSV has been reported in onion in the United States $(9,10,12,14,22-$ $24,32,34,40,46)$ and worldwide (3-8,13,19,21,25,27,29,31,33, 35,41-44,49). In Georgia, IYSV was first found in onion in the Vidalia region in 2003 (34). Phylogenetic analysis of the IYSV isolates from Georgia and elsewhere indicated a high $N$-gene (capsid protein gene) sequence homology between IYSV isolates from Georgia and Peru (38). This revealed that the virus was most likely introduced into the Vidalia region through imported Peruvian onion. Onion growers in the Vidalia onion zone (VOZ) often resort to repacking imported Peruvian onion during the off-season to minimize downtime for their equipment and may have inadvertently introduced IYSV into Georgia by discarding imported onion bulbs in cull piles (38).

IYSV is transmitted by onion thrips, Thrips tabaci (Lindeman) (Thysanoptera: Thripidae), in a persistent, circulative, and propagative manner (35). Onion thrips and tobacco thrips, Frankliniella fusca (Lindeman), are two common thrips species found on onion in Georgia (48). The vector status of $F$. fusca is currently being investigated but preliminary findings indicate that $F$. fusca can also transmit IYSV (R. Srinivasan, unpublished data). Since its first detection in Georgia in 2003, IYSV has been found in low levels every year in onion. Onion plants are grown as a winter crop in Georgia. The seedbeds are planted in September to October; transplants are set in November to January and harvested in April to May. This indicates that the virus has to survive on alternate hosts

Corresponding author: C. Nischwitz,

E-mail: claudia.nischwitz@usu.edu

Accepted for publication 28 February 2012.

http://dx.doi.org/10.1094/PDIS-09-11-0747-RE

(C) 2012 The American Phytopathological Society during summer. Typically, numerous other crops that are hosts of another Tospovirus sp. (Tomato spotted wilt virus) are cultivated in summer. To date, none of the commonly grown crops in and around the VOZ, such as soybean, cotton, peanut, tomato, and pepper, have tested positive for IYSV. Across the United States, several weeds have tested positive for IYSV $(15,16,45)$. Susceptibility of other hosts has been reported by mechanical inoculation $(1,17)$.

In 2007, numerous weed species were collected from areas adjacent to an onion cull pile and from other areas in the VOZ, and were tested for IYSV. Only one plant species, spiny sowthistle, Sonchus asper (L.) Hill, tested positive by enzyme-linked immunosorbent assay (ELISA). The presence of the virus was confirmed with reverse-transcription polymerase chain reaction (RT-PCR) followed by partially sequencing the coat protein gene (36). Other weed species tested included Oenothera laciniata Hill, Verbena rigida Spreng., Solidago canadensis L., Amaranthus retroflexus L., Wahlenbergia marginata (Thunb.) A. DC., Lonicera flava Sims, Passiflora incarnata L., Richardia scabra L., and Portulaca pilosa L. Sowthistle plants are native to Europe and were introduced into North America. Two species are found in Georgia: spiny sowthistle (Sonchus asper) and common sowthistle (S. oleraceus (L.)). They are both considered annuals. Spiny sowthistle is more common along roadsides, fences, and railroads and in waste areas and was the only sowthistle species tested.

The objectives of this study were to (i) conduct a multiyear survey across Georgia to determine the extent of the spread of IYSV in sowthistle within and outside of the VOZ and (ii) evaluate the ability of sowthistle to serve as a suitable host for T. tabaci and as an inoculum source for IYSV.

\section{Materials and Methods}

Sample collection. In 2007, the survey of spiny sowthistle plants included sites in 42 counties both within and outside the VOZ (Fig. 1). The sample size was a minimum of three samples per site. This was increased to a minimum of five samples per site in 2008 and 25 samples per site in 2009; however, in 2008 and 2009 , sampling was reduced to one site per county. Total samples per year were 184,308 , and 1,519 for 2007, 2008, and 2009, 
respectively. For areas outside of the VOZ, a line transect sampling protocol (47) was used to define sample areas. Line transects were constructed based on compass points from a defined point of origin. Three line transects ran north (by northwest), northwest, and west using the center of the VOZ as the point of origin (Fig. 1). The fourth line transect ran south (by southwest) along the eastern perimeter and parallel to the VOZ (Fig. 1). Samples were collected along the transects every $32 \mathrm{~km}$, which means not every county along the transects was sampled. The global positioning system (GPS) coordinates were recorded for each collection site. Only shoots were collected in 2007 and 2008 but, to determine whether IYSV could survive in the roots of infected sowthistle, roots from selected samples that acted as perennials in 2009 were collected in addition to shoots of the survey. The roots were processed as above.

ELISA testing. Sap was extracted from approximately $1 \mathrm{~g}$ of fresh leaf tissue using a sap extractor and stored in $1 \mathrm{ml}$ of modified extraction buffer (for 1 liter of buffer: 1 packet [50 $\mathrm{ml}$ [ of $20 \times$ phosphate-buffered saline-Tween concentrate [Agdia Inc., Elkhart, IN], $1.3 \mathrm{~g}$ of sodium sulfite [anhydrous], $20 \mathrm{~g}$ of polyvinylpyrrolidone [MW 24,000 to 40,000], $2 \mathrm{~g}$ of chicken egg albumin, $20 \mathrm{~g}$ of Tween-20, and 1 liter of double distilled water; $\mathrm{pH}$ 7.4). The undiluted extract $(100 \mathrm{ml})$ was used for testing. The extract was tested for IYSV using double-antibody sandwich (DAS)-ELISA (Agdia Inc.) following the manufacturer's instructions. Values exceeding three times the mean plus two standard deviations of the healthy negative control were used as a threshold for a positive reaction.

RT-PCR. Total RNA was extracted from leaves or roots using the RNeasy Plant Mini Kit (Qiagen, Valencia, CA). The reaction mixture for the RT-PCR, with a total volume of $50 \mu \mathrm{l}$, contained 25 $\mu \mathrm{l}$ of AccessQuick (Promega Corp., Madison, WI), $1 \mu \mathrm{l}$ of RTTranscriptase ( 5 units/ $\mu$ l; Promega Corp.), $3 \mu \mathrm{l}$ of IYSV-F primer $(10 \mu \mathrm{mol} / \mu \mathrm{l}), 3 \mu \mathrm{l}$ of IYSV-R primer $(10 \mu \mathrm{mol} / \mu \mathrm{l}), 1 \mu \mathrm{l}$ of Q solution (Qiagen), $1 \mu \mathrm{l}$ of bovine serum albumen (25,000 ppm), $2 \mu \mathrm{l}$ of total RNA extract, and nuclease-free distilled water added to obtain the total final volume. Amplicons were purified and sequenced. Sequences were compared with known isolates of IYSV in GenBank using BLAST search.

Mechanical inoculation of sowthistle plants to confirm IYSV infection. Seed were collected from spiny sowthistle flower heads in the spring of 2009 and maintained at $4^{\circ} \mathrm{C}$. Spiny sowthistle seed

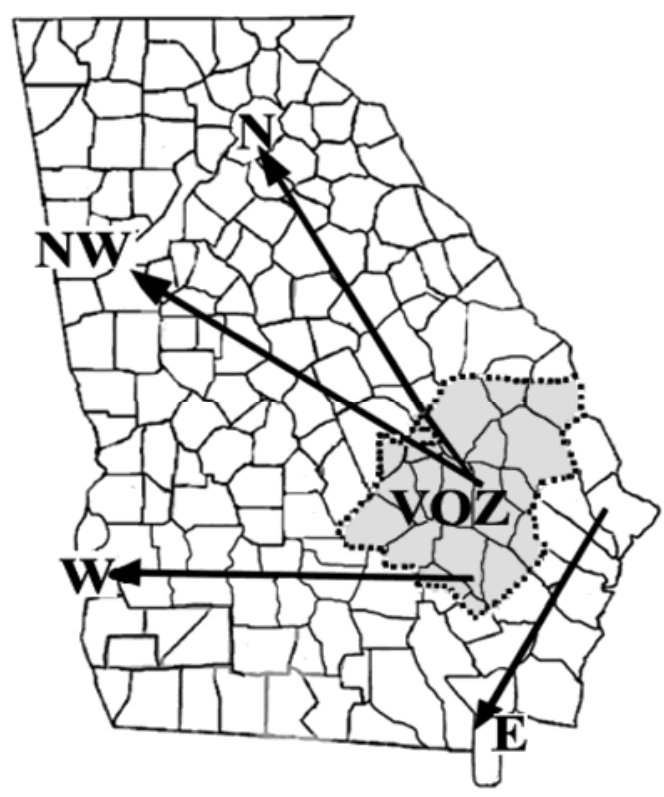

Fig. 1. Areas surveyed for Iris yellow spot virus-infected spiny sowthistle plants within the Vidalia onion-growing zone (VOZ) (shaded gray with dotted outline) and along four line transects (arrows) designated as east $(\mathrm{E})$, north $(\mathrm{N})$, northwest (NW), and west (W), within the state of Georgia in 2007 to 2009. were planted in a commercial potting mix (Miracle-Gro Garden Soil for Flowers and Vegetables; The Scotts Co. LLC, Marysville, $\mathrm{OH})$ in 10-cm-diameter plastic pots in the greenhouse in June and October 2009. When sowthistle plants were 5 to $8 \mathrm{~cm}$ in diameter, the foliage of six plants was mechanically inoculated with IYSV. The source of the inoculum was lisianthus plants that were infected in the greenhouse by IYSV-positive onion thrips. Leaves of IYSVinfected symptomatic lisianthus were ground in liquid nitrogen and $0.1 \%$ phosphate buffer, $\mathrm{pH} 7.0$, containing $0.2 \%$ sodium sulfite, and $0.01 \mathrm{M}$ mercaptoethanol was added. Celite 545 and Carborundum 320 (ThermoFisher Scientific, Waltham, MA), $0.1 \mathrm{~g} / \mathrm{ml}$ each, were added as abrasives to enhance wounding. An equal number of sowthistle plants inoculated with phosphate buffer alone served as negative controls. Plants were incubated for 3 to 5 weeks on the greenhouse bench at 25 to $30^{\circ} \mathrm{C}$ and 80 to $90 \%$ relative humidity (RH) with a 14-h photoperiod in $47.5 \mathrm{~cm}^{3}$ thrips-proof cages (Megaview Science Co., Taichung, Taiwan). The experiment was repeated once with an additional 6 plants for a total of 12 plants inoculated and an equal number of nonexposed plants. Leaves and roots of inoculated plants were tested using DAS-ELISA as described above. Five ELISA-positive IYSV-infected plants were confirmed with RT-PCR as described before. Roots were included in the testing after overwintering sowthistle plants were detected in Georgia.

Maintenance of onion and spiny sowthistle plants for thrips biology and IYSV-transmission studies. 'Pegasus' onion seedlings were planted in 10-cm-diameter and 8-cm-tall pots (Hummert International, Earth City, MO) in a commercial potting mix (Sunshine LP5 Plug Mix; Sun Gro Horticulture Industries, Bellevue, WA), and maintained in a greenhouse at 25 to $30^{\circ} \mathrm{C}$ and 80 to $90 \%$ $\mathrm{RH}$ with a 14-h photoperiod in $47.5-\mathrm{cm}^{3}$ thrips-proof cages (Megaview Science Co.).

Spiny sowthistle seedlings $(<5 \mathrm{~cm}$ tall) were collected from tomato and pepper fields located at the horticultural farm, University of Georgia, Tifton. The collected seedlings were planted in pots and maintained in insect-proof cages under the greenhouse conditions described above. At the time of collection, no onion crops were grown in the farm as well as in a $4.8-\mathrm{km}$ radius from the collection site.

Maintenance of $\boldsymbol{T}$. tabaci. Onion thrips were initially collected from onion plants in Reidsville, GA in 2006. Voucher specimens of T. tabaci are maintained at the Georgia Museum of Natural History, University of Georgia, Athens. Nonviruliferous and viruliferous thrips were maintained on noninfected and IYSV-infected onion plants, respectively, at the Coastal Plain Experiment Station, University of Georgia, Tifton. Nonviruliferous T. tabaci were maintained on healthy onion plants under the conditions described above. Viruliferous thrips were maintained similarly in isolation on IYSV-infected onion plants. New onion seedlings were added as required to maintain thrips colonies.

T. tabaci survival on onion and spiny sowthistle leaf tissue. Spiny sowthistle will only serve as a dead-end host for the virus if it does not support $T$. tabaci survival. Hence, experiments were conducted to assess the ability of T. tabaci to survive and colonize spiny sowthistle. Experiments were conducted in Munger cells $(11.5$ by $9 \mathrm{~cm})$ with excised plant foliage. Two to three excised leaf sections (both onion and sowthistle) of approximately $5 \mathrm{~cm}$ in length were placed in Munger cells lined with a moistened filter paper (Whatman number 2). Ten cells were used for each plant species and each cell was considered as a replicate. Subsequently, the entire experiment was repeated once more with 10 Munger cells ( $n=20$ for all repeats of the experiment). Ten female nonviruliferous $T$. tabaci adults from onion plants were randomly collected and released into each Munger cell. The cells were checked daily, the filter paper was moistened and replaced as required, and fresh leaf tissue was added to support newly hatched T. tabaci larvae. After $96 \mathrm{~h}$, all the adult thrips (dead and alive) were removed to prevent recounting the released adults along with newly emerged adults. The cages were checked daily and the number of nymphs that matured into adults was recorded. Difference in $T$. tabaci adult 
recovery rates in host plants was estimated by analysis of variance using Proc GLM in SAS 9.2 (SAS Institute, Cary, NC).

Thrips-mediated inoculation of spiny sowthistle plants with IYSV. To ensure that the sowthistle plants had no initial IYSV infection, more than $50 \%$ of the field-collected sowthistle plants to be used in the experiment were tested for the presence of IYSV. Foliar samples were tested with RT-PCR using the $N$-gene-specific primers as described above. If any of the spiny sowthistle samples tested positive for IYSV, they were not included in the experiment. Viruliferous T. tabaci adults from onion were used to inoculate spiny sowthistle plants. Ten spiny sowthistle plants $(<10 \mathrm{~cm}$ tall $)$ were inoculated with 10 viruliferous $T$. tabaci adults for each plant. T. tabaci adults that developed on IYSV-infected onion plants were transferred to spiny sowthistle plants using a paint brush (fine camel-hair brush number 2 with aluminum ferrules) and individually enclosed in a Mylar film (Grafix, Cleveland, PA) cage with a copper mesh top (mesh pore size of $170 \mu \mathrm{m}$; TWP, Berkeley, CA). The experiment was repeated once more with 16 plants. An equal number of sowthistle plants in each repeat of the experiment were also individually enclosed in thrips-proof cages. They served as the negative control treatment. After 2 weeks post inoculation, foliar tissue from inoculated plants and control plants was tested with RT-PCR as described above.

\section{Results}

Sowthistle survey. In 2007, $57 \%$ of the counties surveyed within the VOZ had at least one spiny sowthistle sample that tested positive for IYSV whereas, outside of the VOZ, only $25 \%$ of the counties had at least one sample that tested positive (Tables 1 and 2 ). This produced a statewide average of $36 \%$ of all counties surveyed that had at least one sample test positive in 2007. In terms of percentage of total number of samples $(n=184)$, the VOZ and the west, northwest, north, and east transects had 29, 19, 17, 16, and $0 \%$ of the ELISA-positive spiny sowthistle plants, respectively, producing a statewide average of $21 \%$ of all samples testing positive for IYSV in 2007.

In 2008, the percentage of counties within the VOZ that had at least one spiny sowthistle test positive increased to $71 \%$, and the percentage of counties surveyed along the four transects outside the VOZ that tested positive for at least one spiny sowthistle infected with IYSV increased to $46 \%$ (Tables 1 and 2). In terms of total number of samples $(n=308)$, the VOZ and the west, northwest, north, and east transects had 25, 18, 50, 17, and $0 \%$ of the ELISA-positive spiny sowthistle plants, respectively. The statewide average of all counties surveyed where IYSV was detected in spiny sowthistle in 2008 was $21 \%$ (Tables 1 and 2). At least one sample from Berrien County came from new growth occurring on large dried, woody stems from a plant that appeared to survive from 2007 , indicating that sowthistle can act as a perennial in southern Georgia.

By 2009, the average number of counties that had at least one spiny sowthistle test positive for IYSV increased to $79 \%$ within the VOZ and $61 \%$ outside of the VOZ, with a statewide average of $67 \%$ for all counties surveyed (Tables 1 and 2). The spiny sowthistle plants sampled in the survey that were located to the far end of the north transect (White and Hall Counties) and up to $300 \mathrm{~km}$ from the northern edge of the VOZ tested positive for IYSV in all 3 years of the survey (Fig. 2). By the third year, samples from the extreme ends of transects to the west and northwest (Quitman and Carroll Counties) tested positive (Fig. 2C). These two sites were 250 and $320 \mathrm{~km}$ from the western and northwestern edges of the VOZ, respectively. At least one sample from Candler County came from new growth occurring on large dried, woody stems from a plant that appeared to have survived from 2008 and tested positive for IYSV. All spiny sowthistle plants sampled from sites in the east transect, which were 0 to $60 \mathrm{~km}$ from the eastern border of the VOZ, tested negative in all 3 years (Fig 2A-C). Selected samples from both within the VOZ and from selected transects tested positive with RT-PCR. These samples were sequenced and the sequences most closely matched those of IYSV isolates from onion from Georgia (data not shown).

In two greenhouse experiments, the foliage of $50 \%$ of spiny sowthistle plants ( $n=12 /$ trial) mechanically inoculated tested positive for IYSV using ELISA. In all cases, roots of the same plants also tested positive for IYSV. None of the plants showed symptoms of IYSV infection.

T. tabaci survival on onion and spiny sowthistle leaf sections. Newly emerged $T$. tabaci adults were recovered (first adult emerged as early as 10 days post release) from Munger cells with onion and sowthistle foliage. This indicates that both onion and sowthistle can support T. tabaci survival and reproduction. However, the number of adults recovered per 10 adults released varied significantly between onion and sowthistle $(F=6.58 ; \mathrm{df}=1,18 ; P$ $=0.0189$ ) (Table 3 ). In both repeats of the experiment, the number of adults recovered from onion cages was greater than the number of adults recovered from sowthistle cages. Hence, data were pooled for statistical analysis. The number of $T$. tabaci adults recovered for every 10 adults released was 2.89 times greater on onion than on sowthistle. These results indicated that spiny sowthistle also can support T. tabaci populations but not as efficiently as onion.

Thrips-mediated inoculation of spiny sowthistle plants with IYSV. Viruliferous T. tabaci adults transmitted IYSV to inoculated sowthistle plants. RT-PCR yielded approximately 700-bp amplicons from several inoculated plants. None of the noninoculated control plants tested positive for IYSV. IYSV-positive sowthistle plants also did not produce any symptoms upon IYSV infection. Mean IYSV transmission rate in sowthistle was $57.5 \pm 32.5 \%$ (mean \pm standard error).

\section{Discussion}

In a preliminary study, spiny sowthistle was the only weed to test positive for IYSV (36) from a variety of weeds adjacent to an onion cull pile suspected of being the point of IYSV introduction into Georgia (37). Because it was the only IYSV-infected weed and because spiny sowthistle's upright growth habit and height made it possible to locate it from a distance, it was chosen as an indicator plant for this survey. However, a distinct disadvantage of using spiny sowthistle to monitor the movement of IYSV was that it develops no symptoms when infected with the virus. Only testing the samples by ELISA or RT-PCR could determine if the weeds

Table 1. Number of samples in a 3-year survey (2007 to 2009) of spiny sowthistle (Sonchus asper) that tested positive for Iris yellow spot virus by year and by collection site ${ }^{\mathrm{a}}$

\begin{tabular}{|c|c|c|c|c|c|c|c|c|c|}
\hline \multirow[b]{2}{*}{ Zone $^{\mathbf{b}}$} & \multicolumn{3}{|c|}{2007} & \multicolumn{3}{|c|}{2008} & \multicolumn{3}{|c|}{2009} \\
\hline & $n$ & Positive & Pos (\%) & $n$ & Positive & Pos $(\%)$ & $n$ & Positive & Pos (\%) \\
\hline $\mathrm{N}$ & 25 & 4 & 16 & 53 & 9 & 17 & 242 & 22 & 9 \\
\hline NW & 12 & 2 & 17 & 38 & 19 & 50 & 131 & 19 & 15 \\
\hline W & 43 & 8 & 19 & 67 & 12 & 18 & 431 & 48 & 11 \\
\hline E & 19 & 0 & 0 & 42 & 0 & 0 & 158 & 0 & 0 \\
\hline VOZ & 85 & 25 & 29 & 108 & 27 & 25 & 557 & 72 & 13 \\
\hline Total & 184 & 39 & 22 & 308 & 67 & 22 & 1,519 & 161 & 11 \\
\hline
\end{tabular}

a Abbreviations: $n=$ number of samples, Positive = number that tested positive, and Pos $(\%)=$ percent positive.

${ }^{\mathrm{b}} \mathrm{N}=$ north, $\mathrm{NW}=$ northwest, $\mathrm{W}=$ west, and $\mathrm{E}=$ east transects; and $\mathrm{VOZ}=$ Vidalia onion-growing zone. 
were infected with the virus. An interesting facet of this study is that the location where onion crops can be grown and marketed as Vidalia onion is restricted by Georgia law. Because of this restriction, there are virtually no commercial onion crops produced outside of the VOZ. However, spiny sowthistle occurs throughout the state. IYSV was first found in onion in the VOZ only in 2003 (34); therefore, the monitoring of spiny sowthistle plants in different areas of the state provided a unique opportunity to learn about the spread and movement of the virus after its initial introduction across the state and, potentially, to neighboring states.

Over the course of the 3-year survey, the number of counties that had at least one spiny sowthistle test positive for IYSV increased in all survey locations (Tables 1 and 2). From 2007 to 2009, the percentage of all counties in which IYSV was detected in at least one spiny sowthistle increased from 36 to $67 \%$. However, during the same time period, the percentage of counties within the VOZ in which IYSV was detected in at least one spiny sowthistle increased from 57 to $79 \%$. In terms of the number of samples per site, the percentage of spiny sowthistle samples that tested positive for IYSV for all locations in the survey was 21,21 , and $11 \%$ for 2007 , 2008 , and 2009, respectively. Increased rainfall in 2009 may have reduced the level of thrips activity $(27,30)$ and, subsequently, IYSV transmission. Both the percentage of counties where IYSV was detected and the percentage of samples that tested positive were

Table 2. Results of a 3-year survey (2007 to 2009) of spiny sowthistle plants (Sonchus asper) sampled from counties along four transects based on their compass headings from outside of the Vidalia onion-growing zone (VOZ) and from counties within the VOZ in Georgia ${ }^{\mathrm{a}}$

\begin{tabular}{|c|c|c|c|c|c|c|c|c|c|}
\hline \multirow[b]{2}{*}{ Zone, county ${ }^{b}$} & \multicolumn{3}{|c|}{2007} & \multicolumn{3}{|c|}{2008} & \multicolumn{3}{|c|}{2009} \\
\hline & $n$ & Positive & Pos $(\%)$ & $n$ & Positive & Pos $(\%)$ & $n$ & Positive & Pos $(\%)$ \\
\hline \multicolumn{10}{|l|}{ North } \\
\hline 1 Barrow & 3 & 0 & 0 & 7 & 0 & 0 & 20 & 0 & 0 \\
\hline 2 Glascock & 3 & 0 & 0 & 6 & 0 & 0 & 20 & 0 & 0 \\
\hline 3 Hall & 3 & 1 & 33 & 7 & 4 & 57 & 42 & 7 & 17 \\
\hline 4 Hancock & 3 & 0 & 0 & 7 & 0 & 0 & 20 & 0 & 0 \\
\hline 5 Johnson & 3 & 0 & 0 & 7 & 0 & 0 & 61 & 9 & 15 \\
\hline 6 Morgan & 3 & 0 & 0 & 6 & 3 & 50 & 44 & 5 & 11 \\
\hline 7 Washington & 3 & 1 & 33 & 5 & 0 & 0 & 15 & 0 & 0 \\
\hline 8 White & 4 & 2 & 50 & 8 & 2 & 25 & 20 & 1 & 5 \\
\hline Total & 25 & 4 & 16 & 53 & 9 & 17 & 242 & 22 & 9 \\
\hline \multicolumn{10}{|l|}{ Northwest } \\
\hline 9 Carroll & 3 & 0 & 0 & 8 & 0 & 0 & 42 & 6 & 14 \\
\hline 10 Monroe & 3 & 0 & 0 & 6 & 0 & 0 & 30 & 6 & 20 \\
\hline 11 Spaulding & 3 & 0 & 0 & 9 & 6 & 67 & 26 & 5 & 19 \\
\hline 12 Twiggs & 3 & 2 & 67 & 15 & 13 & 87 & 33 & 2 & 6 \\
\hline Total & 12 & 2 & 17 & 38 & 19 & 50 & 131 & 19 & 15 \\
\hline \multicolumn{10}{|l|}{ West } \\
\hline 13 Ben Hill & 4 & 0 & 0 & 5 & 0 & 0 & 21 & 0 & 0 \\
\hline 14 Berrien & 4 & 2 & 50 & 6 & 1 & 17 & 25 & 6 & 24 \\
\hline 15 Calhoun & 4 & 0 & 0 & 6 & 2 & 33 & 23 & 2 & 9 \\
\hline 16 Coffee & 3 & 0 & 0 & 6 & 0 & 0 & 75 & 12 & 16 \\
\hline 17 Dougherty & 4 & 0 & 0 & 5 & 1 & 20 & 38 & 6 & 16 \\
\hline 18 Irwin & 4 & 3 & 75 & 6 & 2 & 33 & 43 & 2 & 5 \\
\hline 19 Quitman & 4 & 0 & 0 & 5 & 2 & 40 & 20 & 4 & 20 \\
\hline 20 Randolph & 4 & 0 & 0 & 4 & 1 & 25 & 26 & 2 & 8 \\
\hline 21 Terrell & 4 & 0 & 0 & 9 & 2 & 22 & 21 & 0 & 0 \\
\hline 22 Tift & 4 & 3 & 75 & 9 & 1 & 11 & 118 & 10 & 8 \\
\hline 23 Worth & 4 & 0 & 0 & 6 & 0 & 0 & 21 & 4 & 19 \\
\hline Total & 43 & 8 & 19 & 67 & 12 & 18 & 431 & 48 & 11 \\
\hline \multicolumn{10}{|l|}{ East } \\
\hline 24 Charlton & 4 & 0 & 0 & 9 & 0 & 0 & 37 & 0 & 0 \\
\hline 25 Chatham & 4 & 0 & 0 & 9 & 0 & 0 & 37 & 0 & 0 \\
\hline 26 Glynn & 4 & 0 & 0 & 7 & 0 & 0 & 22 & 0 & 0 \\
\hline 27 Liberty & 4 & 0 & 0 & 8 & 0 & 0 & 30 & 0 & 0 \\
\hline 28 Ware & 3 & 0 & 0 & 9 & 0 & 0 & 32 & 0 & 0 \\
\hline Total & 19 & 0 & 0 & 42 & 0 & 0 & 158 & 0 & 0 \\
\hline \multicolumn{10}{|l|}{ VOZ } \\
\hline 29 Appling & 6 & 1 & 17 & 9 & 4 & 44 & 11 & 1 & 9 \\
\hline 30 Bacon & 3 & 0 & 0 & 5 & 0 & 0 & 42 & 4 & 10 \\
\hline 31 Bulloch & 7 & 0 & 0 & 9 & 1 & 11 & 40 & 5 & 13 \\
\hline 32 Candler & 5 & 0 & 0 & 7 & 1 & 14 & 12 & 1 & 8 \\
\hline 33 Emanuel & 4 & 0 & 0 & 8 & 0 & 0 & 15 & 0 & 0 \\
\hline 34 Evans & 5 & 1 & 20 & 7 & 0 & 0 & 86 & 22 & 26 \\
\hline 35 Jeff Davis & 3 & 0 & 0 & 7 & 1 & 14 & 40 & 5 & 13 \\
\hline 36 Jenkins & 3 & 1 & 33 & 6 & 2 & 33 & 12 & 1 & 8 \\
\hline 37 Montgomery & 5 & 2 & 40 & 6 & 2 & 33 & 46 & 1 & 2 \\
\hline 38 Tattnall & 12 & 10 & 83 & 15 & 12 & 80 & 30 & 7 & 23 \\
\hline 39 Telfair & 4 & 0 & 0 & 6 & 0 & 0 & 38 & 0 & 0 \\
\hline 40 Toombs & 9 & 2 & 22 & 5 & 1 & 20 & 102 & 16 & 16 \\
\hline 41Wayne & 9 & 1 & 11 & 9 & 1 & 11 & 38 & 0 & 0 \\
\hline 42 Wheeler & 10 & 7 & 70 & 9 & 2 & 22 & 45 & 9 & 20 \\
\hline Total & 85 & 25 & 29 & 108 & 27 & 25 & 557 & 72 & 13 \\
\hline All & 184 & 39 & 21 & 308 & 66 & 21 & 1519 & 161 & 11 \\
\hline
\end{tabular}

a Abbreviations: $n=$ number of samples; Positive = number of samples that tested positive for Iris yellow spot virus using enzyme-linked immunosorbent assay, where values exceeding three times the mean plus two standard deviations of the healthy negative control were used as a threshold for a positive reaction; and Pos $(\%)=($ Positive $/ n) \times 100$.

${ }^{\mathrm{b}}$ Sites along the north, northwest, west, and east transects; $\mathrm{VOZ}=$ sites in the Vidalia onion-growing zone; and All = a compilation of all sites. 
highest within the VOZ compared with any of the other transects, except for the northwest transect in 2008 and 2009.

IYSV-positive spiny sowthistle plants were eventually found in Carroll and Quitman Counties, both of which share a border with the state of Alabama on the western edge of Georgia. In contrast, IYSV-infected spiny sowthistle plants were never detected in any of the counties that were located along the east transect. This was unexpected because those counties are adjacent to the eastern border of the VOZ. One explanation of the distribution observed would be a directional movement of the virus and its vector to the west and northwest. With 11 to $19 \%$ of sowthistle plants testing positive for IYSV in the north, northwest, and west transects, we would expect to see IYSV-infected plants in the east transect as well. This pattern clearly indicates a movement of the vector and virus in a westerly direction and lack of movement to the east. The most plausible theory of a directional movement would be the directional movement of thrips. Theories such as the movement of either infected plants or of plants carrying viruliferous thrips seem unlikely because onion production is centered in the VOZ and few, if any, onion transplants are exported to other areas of the state. In addition, there are few other types of plants produced in the VOZ for shipment to other areas of the state. Also, many of the sample sites were alongside roads in wooded areas and railroad tracks, and on the borders of corn, cotton, or peanut fields, where movement of plant materials with or without infected thrips is not a common occurrence. The absence of detection of IYSV in spiny sowthistle plants in the counties located in the east transect, which is adjacent to the VOZ, also cast a doubt on the spread of IYSV through movement of infected plant materials or translocation of viruliferous thrips. Movement of thrips through commerce or passive movement via humans would have an equal opportunity of moving the virus in all directions. However, by 2009 , infected spiny sowthistle plants were found 300 to $350 \mathrm{~km}$ west, northwest, and north of the VOZ and not in the east transect. This would not be the first time apparent virus dissemination by thrips occurred against prevailing winds because Gent et al. (17) made similar observations in Colorado. An alternative explanation would be that there is not a directional movement of thrips but, rather, thrips movement would be in all directions and their movement to the east is made more difficult by coastal winds blowing inland off of the Atlantic Ocean. If that is the case, it may only be a matter of time before IYSV moves into counties along the east transect. Regardless of the mechanism affecting the spread, a pattern of a higher incidence of IYSV-infected spiny sowthistle plants was found within the VOZ and in the northern and western part of Georgia. Based on our experiments and field observations, spiny sowthistle cannot be dismissed as the "green bridge". At least two samples from the survey, one each in 2008 and 2009, were recognized as the same plants sampled the previous year. This conclusion was based on GPS coordinates, location of marker flags, and sample wounds on older woody stems that were displaying new shoot growth. Although spiny sowthistle may not be the primary means of IYSV surviving between onion crops, these data indicate that it may be at least one way the virus survives.

The importance of weeds as a reservoir of inoculum for IYSV or serving as a green bridge for IYSV survival between onion crops is not well known. Tospovirus spp., in general, are only acquired by early-instar nymphs and transmitted by second-instar nymphs and adults in a persistent and propagative manner $(20,50)$. Thrips have to survive as nymphs and adults in a weed host in order to successfully transmit the virus to other plant hosts. Hosts that do not support thrips reproduction are often regarded as dead-end hosts for the virus. Munger cell experiments suggest that sowthistle plants support T. tabaci populations at a lower level than onion. The number of T. tabaci adults recovered from sowthistle plants was nearly three times less than onion. Observations also indicated that the nymphal mortality on sowthistle plants was higher than on onion. T. tabaci adults that developed on IYSV-infected onion plants efficiently transmitted IYSV to sowthistle plants. The rate of IYSV transmission was $57.5 \%$. Several field-collected spiny sowthistle plants were used for the transmission experiment, even though $>50 \%$ of the plants were tested for the presence of IYSV through RT-PCR before inoculation; it does not necessarily indicate that all the plants were IYSV free. However, the observed transmission rate was higher than the IYSV infection level recorded in any collection site outside of the VOZ. This suggests that the observed high rate of IYSV transmission $(57.5 \%)$ was influenced by thripsmediated inoculation.

Culbreath et al. (11) outlined criteria to incriminate weed hosts being involved in the epidemiology of TSWV. First, the weed must be a host for the virus. Second, the weed host must support thrips'

Table 3. Thrips tabaci reproduction on onion and spiny sowthistle leaf sections

\begin{tabular}{lccc}
\hline & \multicolumn{3}{c}{ Adults recovered $\left(\right.$ mean \pm SE) $^{\mathbf{a}}$} \\
\cline { 2 - 4 } Host $^{\mathbf{b}}$ & Repeat 1 & Repeat 2 & \multicolumn{1}{c}{ Average $^{\mathbf{c}}$} \\
\hline Onion & $9.90 \pm 2.87$ & $18.80 \pm 7.43$ & $14.35 \pm 4.25$ \\
Sowthistle & $6.60 \pm 1.04$ & $3.30 \pm 1.53$ & $4.95 \pm 1.02$ \\
\hline
\end{tabular}

${ }^{a}$ Adults emerging in each cage were counted in each repeat of the experiment; $\mathrm{SE}=$ standard error.

b T. tabaci reproduction on onion and sowthistle leaf sections was evaluated using Munger cages. Ten adults were released in each cage and removed after $96 \mathrm{~h}$, and the cages were monitored continuously until secondgeneration adults emerged.

c Average of two repeats.

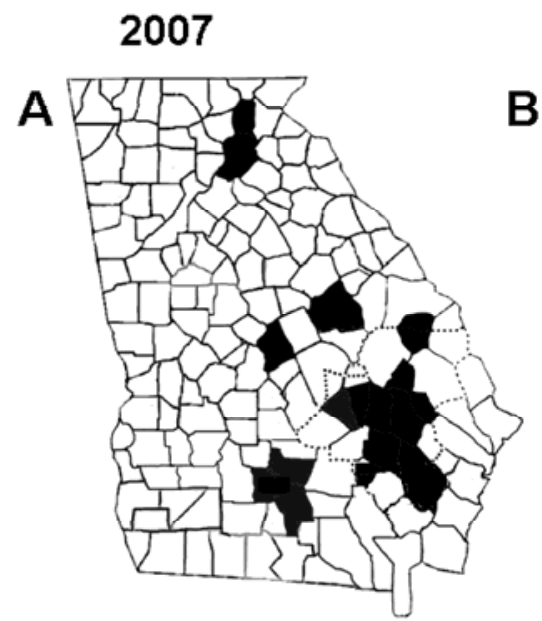

2008

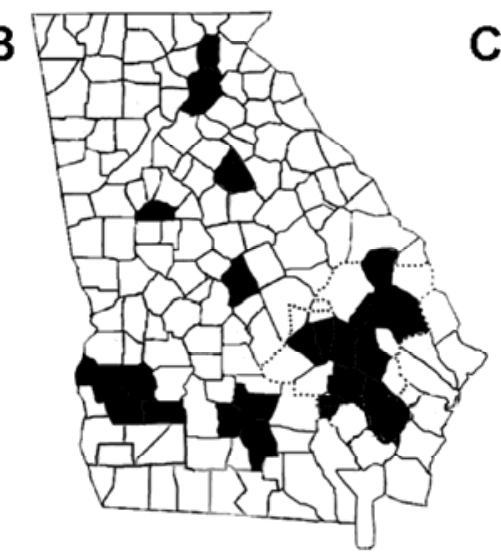

2009

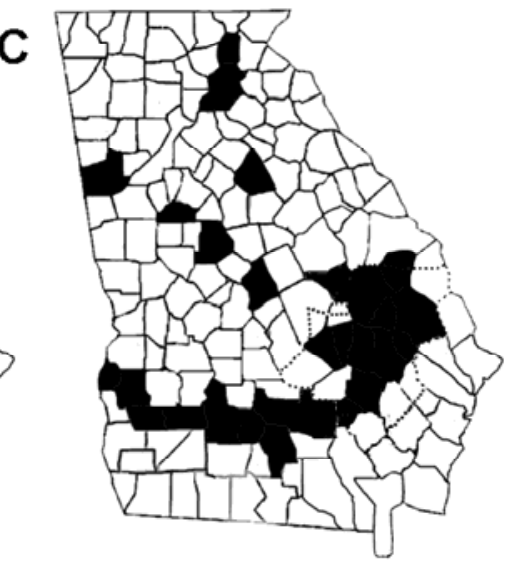

Fig. 2. Results of 2007 to 2009 survey in the state of Georgia for Iris yellow spot virus (IYSV)-infected spiny sowthistle plants. Shaded areas represent counties in which at least one IYSV-infected sowthistle was detected in A, 2007; B, 2008; and C, 2009. 
reproduction for at least one generation. Third, immature thrips have to be able to acquire the virus from the weed. Finally, the weed must be present at a time that corresponds with observed events in the disease cycle. For IYSV epidemics in Georgia, spiny sowthistle fulfills the first three criteria. It remains debatable whether spiny sowthistle serves as a survival host for the virus between onion crops, which is a critical event in the disease cycle; but, to this date, it is the only weed confirmed as a host for IYSV in Georgia. Wild Allium spp. that have been identified as hosts in the state of Washington have tested negative for IYSV in Georgia.

The results also indicate that IYSV and its thrips vectors have the potential to move long distances in a relatively short amount of time. Sites such as those at the extreme end of the north-by-northwest transect testing positive in all 3 years indicate that the virus likely has become endemic and survives locally in the absence of an onion crop. These sites are farther away from the onion-growing zone. Thus, it seems less likely that thrips are transporting the virus from within the VOZ to the exact same areas on an annual basis. For the virus to survive in spiny sowthistle plants, there would have to be large-enough populations of infected spiny sowthistle plants that also act as a perennial. Alternatively, there would have to be an as-yet-unidentified weed host in those locations so that the virus can survive. In this study, we observed that 0.3 and $0.07 \%$ of the spiny sowthistle plants collected in 2008 and 2009, respectively, were from plants that survived as a perennial from the previous year. We also demonstrated that IYSV could be detected in the roots of $50 \%$ of the spiny sowthistle plants mechanically inoculated with the virus. Although there were few spiny sowthistle plants that survived as a perennial in this survey, considering the millions of plants growing statewide, it is possible that the virus could survive in the roots of a significant number of such plants. Furthermore, comparison of the $N$-gene sequences of strains collected in this study with $N$-gene sequences of previously studied strains demonstrates that all of the spiny sowthistle strains of IYSV clustered in the same clade and with previously characterized IYSV strains from Georgia and Peru (data not shown). This indicates that the virus spread to the weeds throughout the state from onion or spiny sowthistle plants within the VOZ and not from independent introductions from western states or elsewhere.

\section{Acknowledgments}

We thank the Vidalia Onion Committee for providing funding for this project and S. Reinhart and the University of Georgia Young Scholars Program for arranging the participation of B. McInnes, a young scholar from Lowndes County High School, Valdosta, GA.

\section{Literature Cited}

1. Bag, S., Druffel, K. L., and Pappu, H. R. 2009. Biological and molecular characterization of Iris yellow spot virus from diverse hosts and geographic regions. (Abstr.) Phytopathology 99:S7.

2. Bag, S., Rogers, P., Watson, R., and Pappu, H. R. 2009. First report of natural infection of garlic with iris yellow spot virus. Plant Dis. 93:839.

3. Bulajić, A., Djekić, I., Jović, J., Krnjajić, S., Vučurović, A., and Krstić, B. 2009. Incidence and distribution of Iris yellow spot virus on onion in Serbia. Plant Dis. 93:976-982.

4. Chatzivassiliou, E. K., Giavachtsia, V., Mehraban, A. H., Hoedjes, K., and Peters, D. 2009. Identification and incidence of Iris yellow spot virus, a new pathogen in onion and leek in Greece. Plant Dis. 93:761.

5. Córdoba-Sellés, C., Martínez-Priego, L., Muńoz-Gómez, R., and JordáGutiérrez, C. 2005. Iris yellow spot virus: a new onion disease in Spain. Plant Dis. 89:1243.

6. Cortês, I., Livieratos, I. C., Derks, A., Peters, D., and Kormelink, R. 1998. Molecular and serological characterization of Iris yellow spot virus, a new and distinct tospovirus species. Phytopathology 88:1276-1282.

7. Cosmi, T., Marchesini, E., and Martini, G. 2003. Presence and spread of tospovirus and thrip vectors in Veneto. Inf. Agrar. 59:69-72.

8. Coutts, B. A., McMichael, L. A., Tesoriero, L., Rodoni, B. C, Wilson, C. R., Wilson, A. J., Persley, D. M., and Jones, R. A. C. 2003. Iris yellow spot virus found infecting onions in three Australian states. Aust. Plant Pathol. 32:555-557.

9. Creamer, R., Sanogo, S., Moya, A., Romero, J., Molina-Bravo, R., and Cramer, C. 2004. Iris yellow spot virus on onion in New Mexico. Plant Dis. 88:1049.

10. Crowe, F. J., and Pappu, H. R. 2005. Outbreak of Iris yellow spot virus in onion seed crops in central Oregon. Plant Dis 89:105.
11. Culbreath, A. K, Todd, J. W, and Brown, S. L. 2003. Epidemiology and management of tomato spotted wilt in peanut. Annu. Rev. Phytopathol. 41:53-75.

12. Derks, A. F. L. M., and Lemmers, M. E. C. 1996. Detection of tospoviruses in bulbous crops and transmissibility by vegetative propagation. Acta Hortic. 432:132-137.

13. Doi, M., Zen, S., Okuda, M., Nakamura, H., Kato, K., and Hanada, K. 2003. Leaf necrosis disease of Lisianthus (Eustoma grandiflorum) caused by Iris yellow spot virus. Jpn. J. Phytopathol. 68:181-188.

14. Du Toit, L. J., Pappu, H. R., Druffel, K. L., and Pelter, G. Q. 2004. Iris yellow spot virus in onion bulbs and seed crops in Washington. Plant Dis. 88:222.

15. Evans, C. K., Bag, S., Frank, E., Reeve, J. R., Ransom, C., Drost, D., and Pappu, H. R. 2009. Natural infection of Iris yellow spot virus in twoscale saltbush (Atriplex micrantha) growing in Utah. Plant Dis. 93:430.

16. Evans, C. K., Bag, S., Frank, E., Reeve, J. R., Ransom, C., Drost, D., and Pappu, H. R. 2009. Green foxtail (Setaria viridis), a naturally infected grass host of Iris yellow spot virus in Utah. Plant Dis. 93:670.

17. Gent, D., du Toit, L. J., Fichtner, S. F., Mohan, S. K., Pappu, H. R, and Schwartz H. F. 2006. Iris yellow spot virus: an emerging threat to onion bulb and seed production. Plant Dis. 90:1468-1480.

18. Gent, D. H., Schwartz, H. F, and Khosla, R. 2004. Distribution and incidence of Iris yellow spot virus in Colorado and its relation to onion plant population and yield. Plant Dis. 88:446-452.

19. Gera, A., Cohen, J., Salomon, R., and Raccah, B. 1998. Iris yellow spot tospovirus detected in onion in Israel. Plant Dis. 82:127.

20. German, T. L., Ullman, D. E., and Moyer, J. W. 1992. Tospoviruses: diagnosis, molecular biology, phylogeny, and vector relationships. Annu. Rev. Phytopathol. 30:315-348.

21. Ghotbi, T., Shahraeen, N., and Winter, S. 2005. Occurrence of tospoviruses in ornamental and weed species in Markazi and Tehran provinces in Iran. Plant Dis. 89:425-429.

22. Hall, J. M., Mohan, K., Knott E. A., and Moyer, J. W. 1993. Tospoviruses associated with scape blight of onion (Allium cepa) seed crops in Idaho. Plant Dis. 77:952

23. Hoepting, C. A., Allen, J. K., Vanderkooi, K. D., Hovius, M. Y., Fuchs, M. F., Pappu, H. R., and McDonald, M. R. 2008. First report of Iris yellow spot virus on onion in Canada. Plant Dis. 92:318.

24. Hoepting, C. A., Schwartz, H. F., and Pappu, H. R. 2007. First report of Iris yellow spot virus on onion in New York. Plant Dis. 91:327.

25. Huchette, O., Bellamy, C., Filomenko, R., Pouleau, B., Seddas, S., and Pappu, H. R. 2008. Iris yellow spot virus on shallot and onion in France. Online. Plant Health Progress. Online publication. doi:10.1094/PHP-20080610-01-BR

26. Jones, D. R. 2005. Plant viruses transmitted by thrips. Eur. J. Plant Pathol. 113:119-157.

27. Kirk, W. D. J. 1997. Distribution, abundance, and population dynamics. Pages 217-258 in: Thrips as Crop Pests. T. Lewis, ed. CAB, Wallingford, Oxon, UK.

28. Kritzman, A., Beckelman, H., Alexandrov, S., Cohen, J., Lampel, M., Zeidan, M., Raccah, B., and Gera, A. 2000. Lisianthus leaf necrosis a new disease of lisianthus caused by Iris yellow spot virus. Plant Dis. 84:1185-1189.

29. Leinhos, G., Muller, J., Heupel, M., and Krauthausen, H.-J. 2007. First report of Iris yellow spot virus in bunching and bulb onion crops in Germany. Nachrichtenbl. Dtsch. Pflanzenschutzdienstes (Braunschweig) 59:310-312.

30. Lewis, T. 1997. Flight and dispersal. In: Thrips as Crop Pests. T. Lewis, ed. CAB, Wallingford, Oxon, UK.

31. Mavric, I., and Ravnikar, M. 2000. Iris yellow spot tospovirus in Slovenia. Pages 223-225 in: Proc. Congr. Eur. Found. Plant Pathol. 5th. Taormina, Italy.

32. Miller, M. E., Saldana, R. R., Black, M. C., and Pappu, H. R. 2006. First report of Iris yellow spot virus on onion (Allium cepa) in Texas. Plant Dis. 90:1359.

33. Mullis, S. W., Gitaitis, R. D, Nischwitz, C., and Csinos, A. S. 2006. First report of onion (Allium cepa) naturally infected with Iris yellow spot virus in Peru. Plant Dis. 90:377.

34. Mullis, S. W., Langston, D. B., Jr., Gitaitis, R. D., Sherwood, J. L., Csinos, A. S., Sparks, A. N., Torrance, R. L., and Cook, M. J. I. V. 2004. First report of Vidalia onion (Allium cepa) naturally infected with Tomato spotted wilt virus and Iris yellow spot virus (family Bunyaviridae, genus Tospovirus) in Georgia. Plant Dis. 88:1285.

35. Nagata, T., Almeida, A. C. L., Resende, R. O., and de Avila, A. C. 1999 The identification of the vector species of Iris yellow spot tospovirus occurring on onion in Brazil. Plant Dis. 83:399.

36. Nischwitz, C., Gitaitis, R. D., Mullis, S. W., Csinos, A. S., Langston, D. B., Jr. 2007. First report of Iris yellow spot virus in spiny sowthistle (Sonchus asper) in the United States. Plant Dis. 91:1518.

37. Nischwitz, C., Mullis, S. W., Csinos, A. S., Langston, D. B., Sparks, A. N., Torrance, R. L., Rafael Mallaupoma, Z. C., Inguil Rojas, E. H., and Gitaitis, R. D. 2006. Phylogenetic analysis of the N gene links Georgia strains of Iris yellow spot virus to strains from Peru. (Abstr.) Phytopathology 96:S84.

38. Nischwitz, C., Pappu, H. R., Mullis, S.W., Langston, D. B., Jr., Sparks, A N., Csinos, A. S., and Gitaitis, R. D. 2007. Phylogenetic analysis of Iris yel 
low spot virus isolates from onion (Allium cepa) in Georgia (USA) and Peru. J. Phytopathol. 155:531-535.

39. Okuda, M., and Hanada, K. 2001. RT-PCR for detecting five distinct Tospovirus species using degenerate primers and dsRNA template. J. Virol. Methods 96:149-156.

40. Poole, G. J., Pappu, H. R., Davis, R. M., and Turini, T. A. 2007. Increasing outbreaks and impact of Iris yellow spot virus in bulb and seed onion crops in the Imperial and Antelope Valleys of California. Plant Health Progress. Online publication. doi:10.1094/PHP-2007-0508-01-BR

41. Pozzer, L., Bezerra, I. C., Kormelink, R., Prins, M., Peters, D., de O. Resende, R., and de Ávila, A. C. 1999. Characterization of a tospovirus isolate of Iris yellow spot virus associated with a disease in onion fields in Brazil. Plant Dis. 83:345-350.

42. Ravi, K. S., Kitkaru, A. S, and Winter, S. 2006. Iris yellow spot virus in onions: a new tospovirus record from India. Plant Pathol. 55:288.

43. Robène-Soustrade, I., Hostachy, B., Roux-Cuvelier, M., Minatchy, J., Hédont, M., Pallas, R., Couteau, A., Cassam, N., and Wuster, G. 2006. First report of Iris yellow spot virus in onion bulb- and seed-production fields in Réunion Island. Plant Pathol. 55:288.
44. Rosales, M., Pappu, H. R., López, L., Mora, R., and Aljaro, A. 2005. Iris yellow spot virus in onion in Chile. Plant Dis. 89:1245.

45. Sampangi, R. K., Mohan, S. K., and Pappu, H. R. 2007. Identification of new alternative weed hosts for Iris yellow spot virus in the Pacific Northwest. Plant Dis. 91:1683.

46. Schwartz, H. F., Brown, W. M., Jr., Blunt, T., and Gent, D. H. 2002. Iris yellow spot virus on onion in Colorado. Plant Dis. 86:560.

47. Smith, R. L. 1966. Ecology and Field Biology. Harper \& Row Publishers, New York.

48. Sparks, A., Diffie, S., and Riley, D. G. 2011. Thrips species composition on onions in the Vidalia production region of Georgia. J. Entomol. Sci. 46:40-

49. Ward L, I., Perez-Egusquiza, Z., Fletcher, J. D., Ochoa Corona, F. M., Tang, J. Z, Liefting, L.W., Martin, E. J, Quinn, B. D., Pappu, H. R., and Clover G. R. G. 2008. First report of Iris yellow spot virus on Allium cepa in New Zealand. New Disease Reports. http://www.bspp.org.uk/publications/newdisease-reports/july2008/2008-43.asp

50. Whitfield, A. E, Ullman, D. E, and German, T. L. 2005. Tospovirus-thrips interactions. Annu. Rev. Phytopathol. 43:459-489. 